\title{
Organization of carbamoyl-phosphate synthase genes in Neisseria gonorrhoeae includes a large, variable intergenic sequence which is also present in other Neisseria species
}

\author{
Fiona S. Lawson, ${ }^{1}$ Finola M. Billowes ${ }^{1}$ and Jo-Anne R. Dillon ${ }^{1,2} \dagger$ \\ Author for correspondence: Jo-Anne R. Dillon. Tel: +1 613562 5459. Fax: +1 6135625452. \\ e-mail: jdillon@labsun1.med.uottawa.ca
}

1 Department of Biology, University of Ottawa, Ottawa, Ontario, Canada

2 National Laboratory for Sexually Transmitted Diseases, Laboratory Centre for Disease Control, Ottawa, Ontario, Canada
The carbamoyl-phosphate synthase (CPS) enzyme in prokaryotes is a heterodimer, encoded by genes commonly called carA and carB. In most prokaryotes examined, these genes are separated by up to 24 bp and are cotranscribed. In Pseudomonas aeruginosa, carA and carB are also co-transcribed, but are separated by 682 bp. We have determined the complete DNA sequence of the carA and carB genes of Neisseria gonorrhoeae strain CH811. carA (1125 bp) and carB (3237 bp) are similar in size and sequence to other prokaryotic CPS genes, however they are separated by an intervening sequence of 3290 bp which has no similarity to the intervening sequence between other CPS genes; furthermore, putative transcription terminators are found downstream of both carA and carB. Several neisserial repetitive sequences were identified within the $9 \mathrm{~kb}$ sequenced, as well as novel 120 and 150 bp repeats (designated RS6 and RS7, respectively) which were found within the intervening sequence between carA and carB. To determine whether the intervening sequence observed in $N$. gonorrhoeae $\mathrm{CH811}$ was not unusual, the sequence between carA and CarB was amplified by PCR from 30 isolates of $N$. gonorrhoeae. The intervening sequence was found to vary in size, from approximately $\mathbf{2 . 2}$ to $3.7 \mathrm{~kb}$, although the carA and carB genes themselves did not vary in size in isolates with functional CPS enzyme. A similar large, variably sized intervening sequence was also found between the carA and carB genes of 12 isolates of $N$. meningitidis and 18 commensal Neisseria isolates comprising nine species. This unexpected organization of the CPS genes in $\mathbf{N}$. gonorrhoeae is therefore widespread throughout the genus Neisseria.

Keywords: Neisseria gonorrboeae, carbamoyl-phosphate synthase (glutamine-hydrolysing), arginine biosynthesis, pyrimidine biosynthesis, Neisseria species

\section{INTRODUCTION}

Carbamoyl-phosphate synthase (CPS; EC 6.3.5.5) catalyses the formation of carbamoyl-phosphate from $\mathrm{CO}_{2}$, ATP and glutamine; the first step in the arginine and

\footnotetext{
† Present address: Department of Microbiology and Immunology, Faculty of Medicine, University of Ottawa, 451 Smyth Road, Ottawa, Ontario, Canada, K1H 8M5

Abbreviation: CPS, carbamoyl-phosphate synthase.

The GenBank accession number for the nucleotide sequence reported in this paper is U11295.
}

pyrimidine biosynthetic pathways. Prokaryotic CPS is a heterodimer, encoded by genes commonly called car $A$ and $\operatorname{car} B$. These genes have been fully or partially sequenced in at least six prokaryotes, and in all instances are found to be co-transcribed in the order car $A$-carB. In most prokaryotes examined these genes overlap or are separated by a small intervening sequence. In Escherichia coli, Salmonella typhimurium and Pseudomonas stutzeri these genes are separated by 17,18 and $24 \mathrm{bp}$, respectively (Piette et al., 1984; Kilstrup et al., 1988; Kwon et al., 1994), and the corresponding pyrimidine-specific CPS genes in Bacillus caldolyticus and Bacillus subtilis overlap by 8 and $11 \mathrm{bp}$, respectively (Quinn et al., 1991; Ghim et al., 
1994). car $A$ and $\operatorname{car} B$ in Pseudomonas aeruginosa, however, are separated by an intervening sequence of $682 \mathrm{bp}$ which contains an unidentified ORF (Kwon et al., 1994).

Initial interest in the CPS enzyme of Neisseria gonorrboeae arose from the natural occurrence of CPS deficiencies in $10-20 \%$ of clinical isolates (Catlin \& Nash, 1978; Shinners \& Catlin, 1982; Li, 1994). A single glutaminedependent CPS enzyme was previously demonstrated in N. gonorrboeae (Shinners \& Catlin, 1982). Subsequently, the $\operatorname{car} A$ and $\operatorname{car} B$ genes were cloned from $N$. gonorrboeae strain CH811 into the phage $\lambda$, and selected by complementation of E. coli mutants (Picard \& Dillon, 1989). We now report the complete DNA sequence of these car $A$ and $c a r B$ genes. These gonococcal CPS genes are separated by a novel intervening sequence of $3290 \mathrm{bp}$, and putative transcription terminators are found downstream of both genes. Examination of other gonococcal isolates, and isolates of other Neisseria species, indicates that a similar large intervening sequence is found between $\operatorname{car} A$ and car $B$ in species throughout the genus, however, this sequence varies in size both within and between species.

\section{METHODS}

Bacterial strains, growth conditions and plasmids. car $A$ and car $B$ were previously cloned from Neisseria gonorrboeae strain $\mathrm{CH} 811$ (auxotype/serotype/plasmid class : non-requiring/1B2/plasmid free) into EMBL4 to produce clone EFP10 (Picard \& Dillon, 1989). The vector pBluescriptII $\mathrm{KS}(+)$ was used for subcloning gonococcal DNA fragments and clones were maintained in $E$. coli JM83. The $E$. coli car $A B$ genes used in hybridization experiments were obtained from plasmid pMC50 provided by R. Cunin (Vrije Universiteit Brussel, Brussels, Belgium). The sequence between $\operatorname{car} A$ and $c a r B$ was investigated from isolates of $N$. gonorrboeae and other $N$ eisseria species listed in Table 1. Gonococcal isolates were selected from the culture collection of the National Laboratory for Sexually Transmitted Diseases (NLSTD), Laboratory Centre for Disease Control (LCDC), Canada, with the exception of isolates MS11-ms and FA1090 which were obtained from J. G. Cannon (University of North Carolina, USA). Isolates chosen from the NLSTD culture collection vary in their geographic source in Canada and date of isolation (from 1988 to 1992), with the exception of CH811 which was isolated in Chile in 1982. Isolates FA1090 and MS11ms are described by West \& Clark (1989). The auxotype of each strain was determined by the method of Hendry \& Stewart (1979), and serotyping was performed as described by Knapp et al. (1984). Chromosomal DNA from $N$. meningitidis and commensal Neisseria species was provided by C. Strathdee (National Laboratory for Special Pathogens, LCDC, Canada). These isolates had been speciated using standard identification criteria (Vedros, 1984) at the National Laboratory for Bacteriology (LCDC, Canada). Gonococcal isolates were stored frozen at $-70^{\circ} \mathrm{C}$ in Brain-Heart Infusion containing $20 \%$ glycerol. They were subcultured on GC medium base (Difco) supplemented with Kellogg's defined supplement, for 18-24 h in the presence of $5 \% \mathrm{CO}_{2}$, in a humid environment, at $35^{\circ} \mathrm{C}$. $E$. coli was grown on tryptic soy agar supplemented with ampicillin $\left(100 \mathrm{mg} \mathrm{l}^{-1}\right)$ at $37^{\circ} \mathrm{C}$, for $18-24 \mathrm{~h}$.

DNA manipulations. DNA was extracted from Neisseria spp. and E. coli as described by Dillon et al. (1985) and Birnboim \& Doly (1979), and purified by either phenol-chloroform extraction/ethanol precipitation, caesium chloride density gradient ultracentrifugation, or by use of the Wizard Minipreps
DNA Purification System of Promega. Restriction endonucleases were obtained from Boehringer Mannheim or Gibco BRL and used according to the manufacturers' instructions. DNA was electrophoresed in $1 \%(\mathrm{w} / \mathrm{v})$ agarose gels, visualized by staining in $0.5 \mu \mathrm{g}$ ethidium bromide $\mathrm{ml}^{-1}$ with exposure to $\mathrm{UV}$, and photographed using the GelPrint 2000i digital imaging system (Bio/Can Scientific).

DNA sequencing and analysis of pFL35 and pFL50. DNA sequences were determined by the method of Sanger et al. (1977) using a combination of deletion clones (produced using the Erase-a-Base kit of Promega) and synthetic oligonucleotide primers (selected using the PrimerDesigner computer program, and prepared by General Synthesis and Diagnostics, Toronto, Ontario). Both manual and automated DNA sequencing methods were used to sequence both strands of DNA. For manual sequencing, Sequenase (USB) and TaqTrack (Promega) DNA sequencing kits were used, and electrophoresis was performed using the Model S2 sequencing gel apparatus of Gibco BRL with $6 \%(\mathrm{w} / \mathrm{v})$ polyacrylamide denaturing gels. For automated sequencing, the PRISM Ready Reaction DyeDeoxy Terminator Cycle Sequencing Kit (Applied Biosystems) and Centri-Sep Spin Columns (Princeton Separations) were used to prepare reactions for the Applied Biosystems Model 373A DNA Sequencing System. DNA sequences were analysed using the MICROGENIE (Beckman Instruments) and PC/GENE (IntelliGenetics) computer programs, and compared to Genbank and EMBL databanks up to and including database submission releases for June, 1994. Alignments of the deduced protein sequences from the CPS gene sequences were obtained using the CLUSTAL multiple sequence alignment method of the GDE (genetic data environment) version 2.2 computer program. Default settings were used with the exception of a fixed gap penalty of 40 . DNA alignments were deduced from the amino acid alignment.

PCR protocols. Primers homologous to the $3^{\prime}$ end of $\operatorname{car} A$ (107-73 bp from the $3^{\prime}$ end of $\operatorname{car} A$ ) and the $5^{\prime}$ end of $\operatorname{car} B$ (51-75 bp from the $5^{\prime}$ end of $c a r B$ ) were selected for amplification of the intervening sequence between $\operatorname{car} A$ and $\operatorname{car} B$. All isolates listed in Table 1 were investigated. The car $A$ gene was amplified using primers homologous to nucleotides 652-667 and 2064-2082 of the sequence submitted to Genbank, and carB was amplified using primers homologous to nucleotides 5290 5309 and 8575-8591 of the same sequence. Amplification of $\operatorname{car} A$ and $\operatorname{car} B$ was performed with the following $11 \mathrm{~N}$. gonorrboeae isolates: CH811, MS11-ms, FA1090, 11860, 9345, NS791, NS384, NS303, NS716, NS1061 and NS686. The GeneAmp PCR kit (Perkin-Elmer, Cetus) was used for all amplifications, with the following reaction conditions: $1 \times$ PCR BufferII, $200 \mu \mathrm{M}$ dNTPs, $1.5 \mathrm{mM} \mathrm{MgCl}_{2}, 2.5 \mathrm{U}$ Taq polymerase per $100 \mu \mathrm{l}, 0.2 \mathrm{mM}$ primer and $0.1 \mu \mathrm{g}$ template DNA in $100 \mu \mathrm{l}$ total volume. All components were kept at $4{ }^{\circ} \mathrm{C}$ (i.e. 'cold start' method) until placed in the thermocycler that had been preheated to $94^{\circ} \mathrm{C}$. The following thermal profile was performed in a Perkin-Elmer 9600 Thermocycler for all amplifications: an initial hold at $94^{\circ} \mathrm{C}$ for $3 \mathrm{~min}, 35$ cycles each of $94^{\circ} \mathrm{C}$ for $15 \mathrm{~s}, 60^{\circ} \mathrm{C}$ for $15 \mathrm{~s}$ and $72^{\circ} \mathrm{C}$ for $3.5 \mathrm{~min}$, and a final hold at $72{ }^{\circ} \mathrm{C}$ for $5 \mathrm{~min}$. Isolates not producing an amplicon using these conditions, were further investigated using a thermal profile with a lower primer annealing temperature $\left(45^{\circ} \mathrm{C}\right.$ instead of $60^{\circ} \mathrm{C}$ ). All results were obtained in duplicate.

DNA hybridizations. Probe preparation entailed isolation of restriction-enzyme-digested DNA fragments from an agarose gel using the QIAEX gel extraction kit (Qiagen). The isolated DNA fragments were labelled by the random priming method with digoxigenin using the Genius kit (Boehringer Mannheim). Plasmid clones or amplicons were digested with appropriate 
Table 1. Phenotypes of Neisseria species

\begin{tabular}{|c|c|c|c|}
\hline Species/isolate & $\begin{array}{c}\text { Auxotype*/serovar/ } \\
\text { Plasmid content/(MDa) }\end{array}$ & Species/isolate & Serovar \\
\hline N. gonorrboeae & & N. meningitidis & \\
\hline CH811 & NR/IB-2/plasmid free & 1503 & $A: 4: P 1 \cdot 9$ \\
\hline NS466 & NR/IB-5/2.6 & 1504 & $A: 4: P 1 \cdot 9$ \\
\hline NS2117 & NR/IB-5/2.6 & 1500 & $\mathrm{~B}: 4: \mathrm{P} 1 \cdot 15$ \\
\hline NS568 & NR/IB-7/2.6 & 1501 & $\mathrm{~B}: 2 \mathrm{~b}: \mathrm{P} 1 \cdot 2$ \\
\hline NS1095 & NR/IB-7/2·6,24.5 & 1514 & $C: 2 a: P 1 \cdot 2$ \\
\hline MS11-ms & NR/IB-9/2.6 & 1518 & $\mathrm{C}: 2 \mathrm{a}: \mathrm{P} 1 \cdot 2$ \\
\hline 11110 & NR/IA-1/2·6,25·2 & 1525 & $C: 2 a: P 1 \cdot 1$ \\
\hline 9228 & 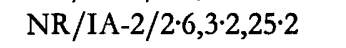 & 1526 & $C: 2 a: P 1 \cdot 1$ \\
\hline 11844 & NR/IA- $2 / 2 \cdot 6,3 \cdot 2,25 \cdot 2$ & 1527 & $C: 2 a: P 1 \cdot 1$ \\
\hline 9345 & 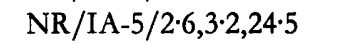 & 1339 & W135 \\
\hline 9881 & NR/IA-5/2.6,3·2,24.5 & 1497 & $\mathrm{Y}$ \\
\hline 9257 & P/IA- $6 / 2 \cdot 6,4 \cdot 5$ & 1498 & $\mathrm{Y}$ \\
\hline 10830 & 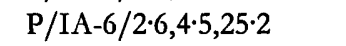 & N. flava 1682 & NA \\
\hline 11860 & 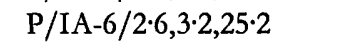 & N. subflava 1683 & NA \\
\hline FA1090 & $\mathrm{P} / \mathrm{I}-3 / 2 \cdot 6$ & N. elongata 1684 & NA \\
\hline NS4702 & P/IB-5/2·6,24.5 & N. mucosa 1685 & NA \\
\hline NS5846 & P/IB-5/2:6,24.5 & N. mucosa 1686 & NA \\
\hline NS667 & $\mathrm{P} / \mathrm{IB}-7 / 2 \cdot 6$ & N. lactamica 1687 & NA \\
\hline NS3019 & $\mathrm{P} / \mathrm{IB}-7 / 2.6$ & N. lactamica 1688 & NA \\
\hline NS8318 & $\mathrm{P} / \mathrm{IB}-7 / 2 \cdot 6$ & N. lactamica 1689 & NA \\
\hline 9073 & OUH/IA- $2 / 2 \cdot 6$ & N. perflava/sicca 1690 & NA \\
\hline 9315 & OUH/IA- $2 / 2 \cdot 6$ & N. perflava/sicca 1691 & NA \\
\hline NS303† & $\mathrm{CUH} / \mathrm{IA}-2 / 2 \cdot 6$ & N. perflava/sicca 1692 & NA \\
\hline NS686† & $\mathrm{CUH} / \mathrm{IA}-2 / 2 \cdot 6$ & N. flavescens 1693 & NA \\
\hline NS716† & $\mathrm{CUH} / \mathrm{IA}-2 / 2 \cdot 6$ & N. flavescens 1694 & NA \\
\hline NS1061† & $\mathrm{CUH} / \mathrm{IA}-2 / 2 \cdot 6$ & N. polysacchareae 1695 & NA \\
\hline NS791† & PCU/IB-3/2.6 & N. polysacchareae 1696 & NA \\
\hline NS2152† & PCU/IB-2/plasmid-free & N. polysacchareae 1697 & NA \\
\hline NS384t & PCU/IB-2/plasmid-free & N. cinerea 1698 & NA \\
\hline NS348t & PCU/IB-7/plasmid-free & N. cinerea 1699 & $\mathbf{N A}$ \\
\hline
\end{tabular}

NA, not applicable.

* The following abbreviations have been used for auxotype: $\mathrm{NR}$, non-requiring; $\mathrm{P}$, proline-requiring; $\mathrm{OUH}$, ornithine-, uracil- and hypoxanthine-requiring; $\mathrm{CUH}$, citrulline-, uracil- and hypoxanthinerequiring; PCU, proline-, citrulline- and uracil-requiring.

† Isolates previously shown by enzyme assays to be CPS-deficient $(\mathrm{Li}, 1994)$.

restriction endonucleases and electrophoresed on $1.0 \%$ agarose gels. DNA was transferred to a nylon membrane by the method of Southern (1975) and hybridization with labelled probe was completed at high stringency $\left(68^{\circ} \mathrm{C}\right.$ in $5 \times \mathrm{SSC}$ with washes in $0.1 \times \mathrm{SSC}, 0.1 \%$ SDS). Hybridizations at lower stringencies used the same solutions but with hybridization and washing temperatures of $60^{\circ} \mathrm{C}$. Blots were visualized using the colorimetric method of the Genius kit protocol (Boehringer Mannheim).

\section{RESULTS AND DISCUSSION}

carA and carB in $\mathbf{N}$. gonorrhoeae CH811 are similar in size and sequence to other prokaryotic CPS genes

The $\operatorname{car} A$ and $\operatorname{car} B$ genes were previously cloned from $N$. gonorrboeae strain $\mathrm{CH} 811$ into $\lambda$ by complementation of $E$. coli mutants, producing clone EFP10 (Picard \& Dillon,
1989). A $5.4 \mathrm{~kb}$ EcoRI-XbaI fragment and a $3.5 \mathrm{~kb}$ EcoRI-XboI fragment from EFP10, which hybridize to all or part of the $E$. coli car $A B$ operon, were subcloned into pBluescriptII $\mathrm{KS}(+)$ to produce pFL50 and pFL35, respectively (Fig. 1). The complete sequence ( 8984 bp) of the gonococcal inserts from pFL35 and pFL50 was then determined. In this sequence, $\operatorname{car} A(1125 \mathrm{bp})$ and $\operatorname{car} B$ (3237 bp) are found in the same orientation and are separated by $3290 \mathrm{bp}$. An additional $876 \mathrm{bp}$ upstream of $\operatorname{car} A$ and an additional $456 \mathrm{bp}$ downstream of $\operatorname{car} B$ were sequenced in these clones.

DNA sequence analysis of the $\operatorname{car} A$ and $\operatorname{car} B$ genes of $N$. gonorrboeae $\mathrm{CH} 811$ showed they have a GC content and codon usage similar to the other gonococcal genes (West \& Clark, 1989) particularly argJ (Martin \& Mulks, 1992) and argF (Martin et al., 1990; data not shown). Also 


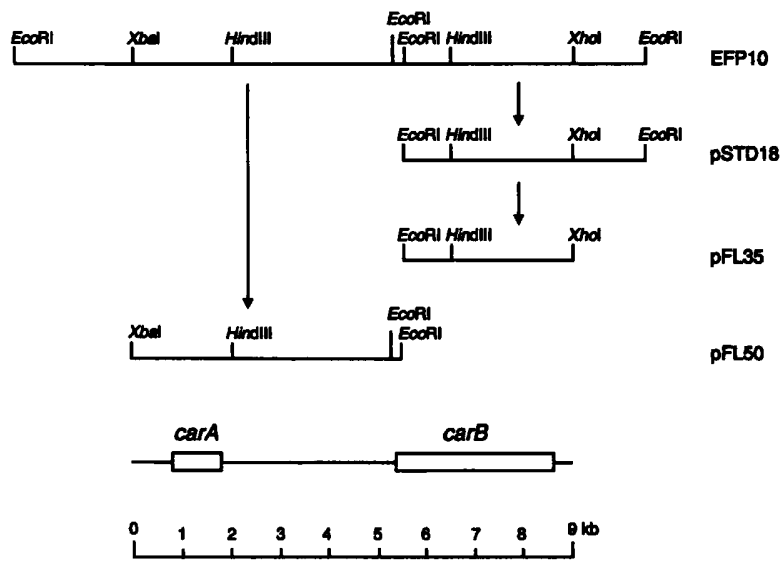

Fig. 1. Location of carA and carB in the gonococcal inserts of phage and plasmid clones. Arrows indicate the progression in the isolation of each clone, which all originate from EFP10. Restriction enzyme sites are indicated above each clonal insert. The relative position of carA and carB, determined by complete DNA sequencing of pFL50 and pFL35, is shown below the clones.

primary sequence analysis indicates that these gonococcal CPS genes are similar in size and sequence to the corresponding genes of other prokaryotes. car $A$, with an ATG start codon and TAA stop codon, encodes a protein of 375 amino acids (predicted molecular mass $40551 \mathrm{Da}$ ). $\operatorname{car} B$, with an ATG start codon and TGA stop codon, encodes a protein of 1079 amino acids (predicted molecular mass $119614 \mathrm{Da}$ ). Alignment (data not shown) of the deduced protein sequence from $\operatorname{car} A$ with deduced protein sequences from the corresponding genes from other prokaryotes shows that the gonococcal sequence is equidistantly related to the Pseudomonas and enteric species homologues, having approximately $65 \%$ similarity with $P$. aeruginosa, $P$. stutzeri, E. coli and $S$. typhimurium, though the sequences from Pseudomonas and enteric species also show approximately $65 \%$ similarity with each other. The gonococcal sequence shows $44 \%$ similarity with $B$. subtilis (pyrimidine-regulated enzyme). Alignment of deduced proteins from $c a r B$ genes reveals that the gonococcal sequence has approximately $66 \%$ similarity with $E$. coli, and $46 \%$ similarity with $B$. subtilis (pyrimidine-regulated). Internal similarity is found between the first third and second third of the gonococcal carB gene ( $34 \%$ similarity at the protein level), similar to the initial report for $E$. coli $\operatorname{carB}$ (Nyunoya \& Lusty, 1983). Fig. 2 shows the deduced amino acid sequence of gonococcal CPS with conserved domains that we have identified by alignment with six prokaryotic and seven eukaryotic CPS sequences. Simmer et al. (1990) also identified conserved domains; however, they did not compare conserved domains using complete CPS gene sequences, since the $5^{\prime}$ end of the hamster CPS gene sequence they were primarily investigating was missing. Highly conserved domains in other CPSs, including the conserved domains reported by Simmer $e t$ al. (1990), are conserved in gonococcal CPS. This includes residues previously found to be reactive in the catalysis of glutamine amide transfer (Amuro et al., 1985). (a)

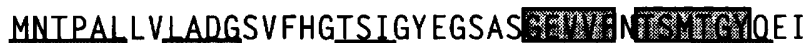

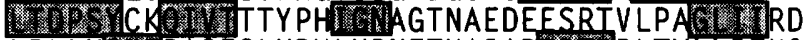
LPLLHSIVRASESLDYLVRNETVAIAD W. RLTMLLREKG QGGAILTGADATVEKAQE LI AAFGSMVGKDLAKEVSCTETYE WTEGEWELGKGFVTPDKOPYHVVAYDFGVKTNI LRI SPRGCR LTVVPAQTSAEDVIALNPWOF LSQRPGDPEPCTYAIEAVQK

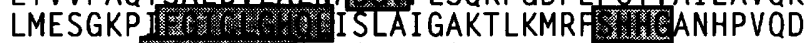
LDSGKVVIIIIIM AVDADTLPANARITHKSLFDNTLQGIE LTDKPVFCFQGWM ASPGPQDVGY LFDKFI GNMKAAKQA

(b)

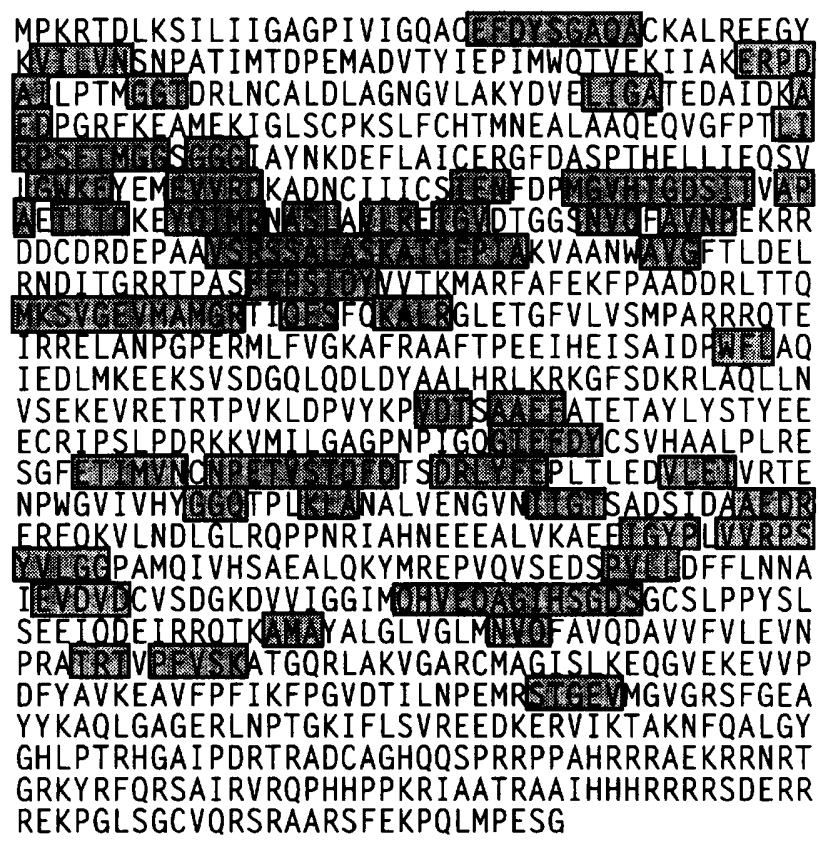

Fig. 2. Deduced amino acid sequence from the carA (a) and carB (b) genes of $N$. gonorrhoeae CH811. Regions highly conserved (boxed) were assigned based on alignments of deduced protein sequences from CPS gene sequences obtained from the following organisms (accession numbers are shown in brackets): human (D90282), rat (M11710, M12318-28), hamster (J05503), Trichosporin cutaneum (L08965), Dictyostelium discoideum (X14533, X55433), Neurospora crassa (J05512), yeast (K02132, K01178, M27174), B. caldolyticus (X73308), B. subtilis (M59757), P. aeruginosa (U04992), P. stutzeri (U04993), S. typhimurium (X13200) and E. coli (J01597). Only regions with three or more consecutive conserved residues are noted (conservative substitutions are included).

\section{carA and carB in $\mathbf{N}$. gonorrhoeae CH811 are separated by a unique large intervening sequence and, unlike other prokaryotes, putative transcription terminators are found downstream of both genes}

Although the CPS genes of $N$. gonorrboeae $\mathrm{CH} 811$ are similar in size and sequence to those of other prokaryotes, their organization is quite different. Firstly, these genes are separated by an unusually large intervening sequence of $3290 \mathrm{bp}$. Most other prokaryotic CPS genes either overlap, or are separated by up to $24 \mathrm{bp}$. Only $P$. aeruginosa PAO1 was shown to have $\operatorname{car} A$ and $\operatorname{car} B$ separated by a $682 \mathrm{bp}$ sequence which contains an unidentified ORF; this ORF has a codon usage consistent 
(a)

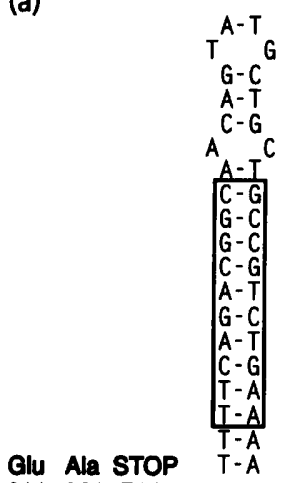

CAA GCA TAA TGA AGAAAGCT (b)

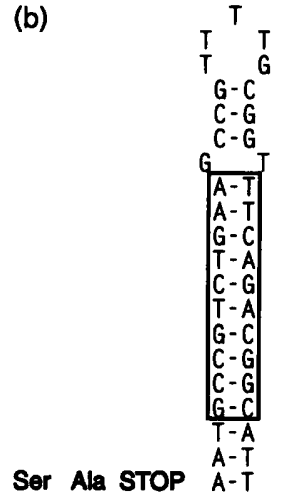

TCA GGT TGA AC TTGTTGCA

Fig. 3. DNA sequence of the putative transcription terminators found downstream of both carA (a) and carB (b) in $N$. gonorrhoeae $\mathrm{CH811}$. Gonococcal uptake sequences are boxed.

with other $P$. aeruginosa genes (Kwon et al., 1994). We found no significant similarity between the $682 \mathrm{bp}$ intervening sequence of $P$. aeruginosa and the corresponding intervening sequence of $N$. gonorrboeae $\mathrm{CH} 811$. In fact, the gonococcal intervening sequence has no significant similarity to any sequences found in Genbank and EMBL (up to June, 1994). Ten ORFs, ranging in size from 75 to $560 \mathrm{bp}$, were identified in this gonococcal intervening sequence; however, based on primary sequence analysis, no obvious function could be determined for these ORFs and none had a codon usage consistent with a gonococcal gene. The codon usage inconsistency is probably a reflection of the significantly lower GC content of this region; $\operatorname{car} A$ and $\operatorname{car} B$ both have a GC content of $57 \%$ while the sequence between $\operatorname{car} A$ and $\operatorname{car} B$ is $43 \%$ GC.

Not only is the intervening sequence between $\operatorname{car} A$ and car B in $N$. gonorrboeae $\mathrm{CH} 811$ quite different from the intervening sequence in $P$. aeruginosa, but in $P$. aeruginosa and all other characterized prokaryotes, no transcription terminators are found between $\operatorname{car} A$ and $\operatorname{car} B$. We have identified putative transcription terminators downstream of both the $\operatorname{car} A$ and $\operatorname{carB}$ genes of $N$. gonorrboeae $\mathrm{CH} 811$.

These putative terminators consist of inverted repeats containing the gonococcal uptake sequence with additional $\mathrm{A}$ or $\mathrm{T}$ residues (Fig. 3). The gonococcal uptake sequence is a $10 \mathrm{bp}$ sequence involved in species-specific uptake of DNA by naturally competent gonococci (Goodman \& Scocca, 1988; Elkins et al., 1991). Recently, Barber et al. (1994) have demonstrated that inverted repeats containing the gonococcal uptake sequence can act as $\rho$-independent transcription terminators in $E$. coli. These results suggest that $\operatorname{car} A$ and $\operatorname{car} B$ in $N$. gonorrboeae may be separately transcribed.

\section{Previously reported repetitive sequences are located upstream of carA, and novel repeats are found within the intervening sequence between carA and carB in $\mathbf{N}$. gonorrhoeae CH811}

Several repetitive sequences were found scattered throughout the $9 \mathrm{~kb}$ region comprising $\operatorname{car} A$ and $\operatorname{car} B$ (Fig. 4), some of which have complex secondary structure. Nine gonococcal uptake sequences were identified as well as eight more containing one mismatch (these mismatches are not necessarily in the same location).

Three other previously characterized repeats, RS3, RS2, and a ' 152 bp repeat' (Haas \& Meyer, 1986; Correia et al., 1988), were identified in the $876 \mathrm{bp}$ of DNA sequence obtained upstream of $\operatorname{car} A$. The sequence $5^{\prime}$ GGGAAT $3^{\prime}$, part of the RS3 class of repeats, is present in seven copies. RS2 is $48 \mathrm{bp}$ long and found in one copy, surrounded by 21 bp inverted repeats. These 21 bp repeats each contain $8 \mathrm{bp}$ inverted repeats containing copies of the 6 bp sequence of RS3. A copy of the ' 152 bp repeat' was also located upstream of $\operatorname{car} A$. This sequence contains flanking 19 bp inverted repeats and is present in at least 20 copies in the gonococcal genome (Correia et al., 1988). This repeat has subsequently been given numerous names such as NR and Ng-rep (Bhat et al., 1991; Lupski \& Weinstock, 1992). For consistency in the naming of repeats, we suggest that this repeat be named RS5.

Within the intervening sequence between the $\operatorname{car} A$ and carB genes of $N$. gonorrboeae $\mathrm{CH} 811$, novel repeats, which
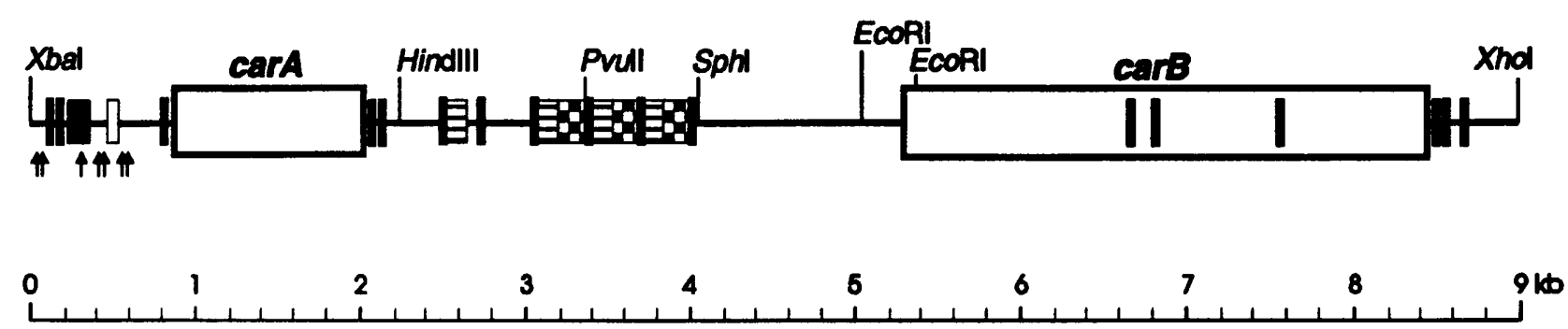

Fig. 4. Schematic diagram of the DNA sequence comprising carA and car $B$ of $N$. gonorrhoeae CH811, showing the location of novel and previously identified repetitive sequences. carA and carB are shown as large hollow boxes. Novel repetitive sequences RS6 and RS7 are indicated by striped and chequered boxes, respectively. Thick black vertical lines mark locations of the gonococcal uptake sequence. Previously reported repeats identified upstream of carA are also shown; arrows denote copies of RS3, the shaded box denotes a copy of the '152 bp repeat' (RS5) and the thin white box denotes a copy of RS2. 
we have named RS6 and RS7, were also detected. RS6 is approximately $130 \mathrm{bp}$ and contains one $9 \mathrm{bp}$ GC-rich inverted repeat. RS7 is $150 \mathrm{bp}$ and contains one $15 \mathrm{bp}$ GC-rich inverted repeat. The relative position of the four copies of RS6 and three copies of RS7 is shown schematically in Fig. 4, where one can see that these repeats are often associated with copies of the gonococcal uptake sequence. A single copy of RS6 is found $450 \mathrm{bp}$ downstream of $\operatorname{car} A$, associated with a gonococcal uptake sequence that is on the complementary strand and which has one mismatch. Three more copies of RS6 are found further downstream from $\operatorname{car} A$, each associated with a copy of RS7. These three units of RS6/RS7 are each flanked by gonococcal uptake sequences which are not on the complementary strand and which have a different single mismatch from the uptake sequence associated with the single copy of RS6. Alignment of the four copies of RS6 indicates that the isolated copy of RS6 (i.e. 450 bp downstream of $\operatorname{car} A$ ) shows the least similarity with the RS6 consensus sequence $(88.9 \%)$. Downstream from this, the three subsequently occurring RS6 sequences (associated with RS7) show progressively increasing levels of similarity with the consensus sequence $(98.3 \%$, $99 \cdot 2 \%$ and $99 \cdot 2 \%$, respectively). The three copies of RS7 show a similar trend when aligned; the copy closest to car $A$ has $92.9 \%$ similarity with the RS7 consensus sequence, while the last two are identical. This suggests a probable succession of origin for these sequences. Both RS6 and RS7 showed no significant similarities with sequences from Genbank or EMBL (up to June, 1994).

\section{A similar large intervening sequence is found in other $\boldsymbol{N}$. gonorrhoeae isolates; however it varies in size}

To determine the universality of the intervening sequence between $\operatorname{car} A$ and $\operatorname{car} B$ in other gonococcal isolates, a PCR protocol was developed to amplify this sequence using primers homologous to the end of $\operatorname{car} A$ and the beginning of carB. The amplicons produced from a template of pFL50 DNA and $N$. gonorrboeae CH811 chromosomal DNA were found to be the same size, approximately $3450 \mathrm{bp}$, corresponding with the size (3473 bp) predicted from the DNA sequence of pFL50, and restriction enzyme analysis of these amplicons with DdeI/Hinfl produced seven similar fragments of predicted size (data not shown). Both amplicons hybridized at high stringency with a $3 \mathrm{~kb}$ HindIII-EcoRI probe (restriction enzyme sites shown in Fig. 4) containing sequences from between $\operatorname{car} A$ and $\operatorname{car} B$ from pFL50 (data not shown).

When 29 other gonococcal isolates were examined, the resulting amplicons were found to vary in size from approximately 3.9 to $2.4 \mathrm{~kb}$ (Table 2 ). These amplicons contain an estimated $74 \mathrm{bp}$ of the $3^{\prime}$ end of $\operatorname{car} A$, and $111 \mathrm{bp}$ of the $5^{\prime}$ end of $c a r B$, therefore the size of the intervening sequences for the isolates studied varies between approximately 3.7 and $2.2 \mathrm{~kb}$. All the amplicons hybridized at high stringency to the $3 \mathrm{~kb} H$ indIII-EcoRI probe containing sequences from between $\operatorname{car} A$ and $\operatorname{car} B$ from pFL50 (data not shown). While amplicons were obtained from all isolates which are known to have a functional CPS enzyme (auxotype NR, P and OUH), only two out of eight isolates with CPS deficiencies (auxotype CUH and PCU) produced amplicons (Table 2). The failure of these isolates to produce an amplicon is probably because one or both of the primer binding regions homologous to the ends of $c a r A$ and $c a r B$ are mutated or absent. No obvious correlations were seen between the size of the amplicon and the date of isolation, isolation site or geographic origin of the isolate. Preliminary data were suggestive that gonococcal isolates of similar auxotype/ serotype/plasmid class (A/S/P class) had amplicons of a similar size. However, due to the small sample size for a given A/S/P class, no definitive conclusions can be made regarding the potential for this sequence to differentiate between classes of isolates or related isolates.

\section{The carA and carB genes themselves do not vary in size in different gonococcal isolates, except for isolates known to be CPS-deficient}

To determine whether the $\operatorname{car} A$ and $\operatorname{car} B$ genes varied in size, primers were selected to amplify these genes from 11 gonococcal isolates, five belonging to different $\mathrm{A} / \mathrm{S} / \mathrm{P}$ classes and producing different amplicon sizes, and six known to have CPS deficiencies (see Methods; data not shown). Of the five isolates known to have functional CPS, all produced amplicons containing $\operatorname{car} A$ of similar predicted size (1431 bp) and all amplicons containing car $B$ were also of similar predicted size (3303 bp). Therefore, the size of the $\operatorname{car} A$ and $\operatorname{car} B$ genes seems to be conserved, even though the intervening sequence between these genes varies. Of the six isolates known to be CPSdeficient, all produced an amplicon of predicted size containing carB. However when amplifying $\operatorname{car} A$, amplicons from the CPS-deficient isolates varied from either no or faint amplicons of predicted size (isolates NS716, NS1061 and NS686), to a smaller (approximately $850 \mathrm{bp}$ ) amplicon (isolate NS303), to an amplicon of expected size and intensity (NS791 and NS384). This variability shows that more than one mutation is responsible for causing the CPS deficiency in these isolates.

\section{The intervening sequence between car $A$ and car $B$ also varies in size in isolates of $N$. meningitidis and commensal Neisseria species}

To determine whether the large intervening sequence observed in gonococcal isolates was also present in other Neisseria species, the protocol used to amplify the intervening sequence from gonococcal isolates was also utilized with isolates of $N$. meningitidis and eight commensal Neisseria species. Amplicons varied in size from approximately 1.4 to $4 \cdot 1 \mathrm{~kb}$ (Table 2). All 12 isolates of $N$. meningitidis, comprising five different serovars, produced amplicons, ranging in size from 2.8 to $3.3 \mathrm{~kb}$. Though the sample size was small, amplicon size was associated with serogroup, except for two isolates from serogroup B, which produced amplicons of 2.8 and $3.3 \mathrm{~kb}$. Of the 18 commensal Neisseria isolates examined, 17 produced 
Table 2. Estimated size of PCR amplicons of the sequence between carA and carB in Neisseria isolates

\begin{tabular}{|c|c|c|c|}
\hline Species/isolate & $\begin{array}{c}\text { Estimated } \\
\text { amplicon } \\
\text { size }(\mathbf{k b})\end{array}$ & Species/isolate & $\begin{array}{c}\text { Estimated } \\
\text { amplicon } \\
\text { size (kb) }\end{array}$ \\
\hline N. gonorrboeae & & N. meningitidis & \\
\hline CH811 & $3 \cdot 4$ & 1503 & $3 \cdot 3$ \\
\hline NS466 & $3 \cdot 4$ & 1504 & $3 \cdot 3$ \\
\hline NS2117 & $3 \cdot 4$ & 1500 & $2 \cdot 8$ \\
\hline NS568 & $3 \cdot 2$ & 1501 & $3 \cdot 3$ \\
\hline NS1095 & $2 \cdot 7$ & 1514 & $3 \cdot 0$ \\
\hline MS11-ms & $3 \cdot 4$ & 1518 & $3 \cdot 0$ \\
\hline 11110 & $3 \cdot 0$ & 1525 & $3 \cdot 0$ \\
\hline 9228 & $3 \cdot 0$ & 1526 & $3 \cdot 0$ \\
\hline 11844 & $3 \cdot 0$ & 1527 & $3 \cdot 0$ \\
\hline 9345 & $2 \cdot 7$ & 1339 & $2 \cdot 8$ \\
\hline 9881 & $2 \cdot 7$ & 1497 & $2 \cdot 8$ \\
\hline 9257 & $3 \cdot 4$ & 1498 & $2 \cdot 8$ \\
\hline 10830 & $3 \cdot 4$ & N. flava 1682 & $2 \cdot 8$ \\
\hline 11860 & $3 \cdot 0$ & N. subflava 1683 & $2 \cdot 7$ \\
\hline FA1090 & $3 \cdot 2$ & N. elongata 1684 & $-t$ \\
\hline NS4702 & $3 \cdot 0$ & N. mucosa 1685 & $2 \cdot 8$ \\
\hline NS5846 & $2 \cdot 7$ & N. mucosa 1686 & $2 \cdot 4$ \\
\hline NS667 & $3 \cdot 4$ & N. lactamica 1687 & $3 \cdot 0$ \\
\hline NS3019 & $3 \cdot 4$ & N. lactamica 1688 & $2 \cdot 4$ \\
\hline NS8318 & $3 \cdot 4$ & N. lactamica 1689 & $2 \cdot 4$ \\
\hline 9073 & $3 \cdot 5$ & N. perflava/sicca 1690 & $3 \cdot 0(2 \cdot 8) \ddagger$ \\
\hline 9315 & 3.9 & N. perflava/sicca 1691 & $4 \cdot 1$ \\
\hline NS303 & $3 \cdot 5$ & N. perflava/sicca 1692 & $1 \cdot 6$ \\
\hline NS686 & -* & N. flavescens 1693 & $3 \cdot 0$ \\
\hline NS716 & $-*$ & N. flavescens 1694 & $2 \cdot 5$ \\
\hline NS1061 & -* & N. polysacchareae 1695 & $2 \cdot 1$ \\
\hline NS791 & $2 \cdot 4$ & N. polysacchareae 1696 & $1 \cdot 7$ \\
\hline NS2152 & $-*$ & N. polysacchareae 1697 & $1 \cdot 8$ \\
\hline NS384 & $-*$ & N. cinerea 1698 & $1 \cdot 5$ \\
\hline NS348 & -* & N. cinerea 1699 & $1 \cdot 4$ \\
\hline
\end{tabular}

* PCR amplicons not produced. All of these isolates are CPS-deficient ( $\mathrm{Li}, 1994)$.

†PCR amplicon not produced. It is not known if the isolate is CPS-deficient.

$\ddagger$ A second, less intense amplicon was also produced from this isolate of approximately $2 \cdot 8 \mathrm{~kb}$ in size.

amplicons (Fig. 5) of 12 different sizes, ranging from $1 \cdot 4$ to $4 \cdot 1 \mathrm{~kb}$. The one isolate not producing an amplicon was the only isolate of $N$. elongata examined, a species that is significantly different from other Neisseria species in that it is a rod and not a diplococcus. Intraspecies variation in amplicon sizes were noted in all species where more than one isolate had been examined. A single amplicon was produced from each isolate with the exception of $N$. perflava/sicca 1690 which produced an amplicon of $3.0 \mathrm{~kb}$ and an amplicon of lesser intensity of $2.8 \mathrm{~kb}$ (Fig. 5, lane C8). Amplicons produced from commensal Neisseria species isolates were in general more variable in size than those from the pathogenic Neisseria isolates, although more species were examined in the commensal group.

The $3 \mathrm{~kb}$ HindIII-EcoRI probe comprising most of the intervening sequence from $N$. gonorrboeae $\mathrm{CH} 811$ hybridized at high stringency to all the amplicons produced from the $N$. meningitidis isolates. However, a lower stringency $\left(60^{\circ} \mathrm{C}\right)$ was required for hybridization with the amplicons produced from commensal Neisseria species. At this lower stringency, 13 out of the 17 amplicons produced from the commensal Neisseria isolates hybridized strongly to the probe, while the remaining four, all with the smallest amplicon sizes, hybridized weakly (data not shown). These results suggest that a large, variable intervening sequence is also present between the $\operatorname{car} A$ and $\operatorname{car} B$ genes of other Neisseria species which has significant similarities to the intervening sequences of $N$. gonorrboeae.

In conclusion, the organization of the $\operatorname{car} A$ and $\operatorname{car} B$ genes in $N$. gonorrboeae is significantly different from that of other previously characterized prokaryotes; a unique, 


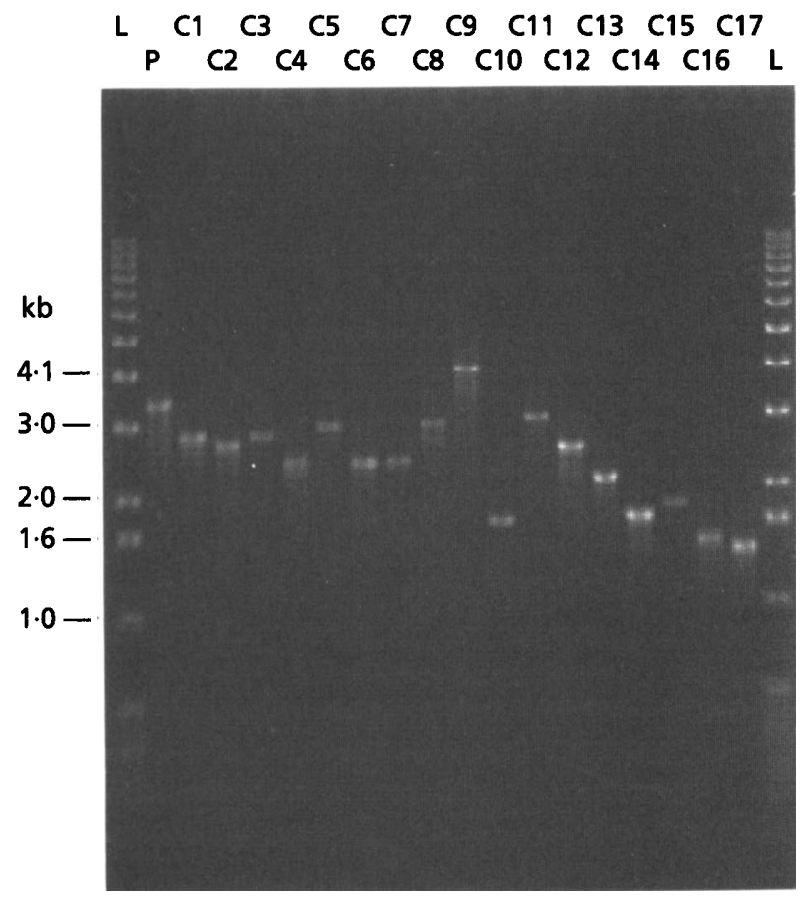

Fig. 5. Electrophoresis of $P C R$ amplicons containing the intervening sequence between carA and car $B$ from 17 commensal Neisseria isolates comprising eight species. Lanes: $L$, $1 \mathrm{~kb}$ ladder; $\mathrm{P}$, amplicon from pFL50 template DNA; C1-C17 contain amplicons from a template of chromosomal DNA from isolates 1682 (C1), 1683 (C2), 1685 (C3), 1686 (C4), 1687 (C5), 1688 (C6), 1689 (C7), 1690 (C8), 1691 (C9), 1692 (C10), 1693 (C11), 1694 (C12), 1695 (C13), 1696 (C14), 1697 (C15), 1698 (C16) and 1699 (C17).

large, variably sized intervening sequence separates the two genes, and putative transcription terminators are found downstream of both $\operatorname{car} A$ and $\operatorname{car} B$. This is the first investigation of CPS gene organization from multiple isolates of the same species, and it has produced the first report of interspecies variation in a sequence proximal to CPS genes. Numerous repetitive sequences are found throughout the sequence comprising the $\operatorname{car} A$ and $\operatorname{car} B$ genes of $N$. gonorrboeae $\mathrm{CH} 811$, including novel repeats found within the intervening sequence. These repeats may play a role in the sequence variation observed. Gonococci are noted for their heterogeneity and their ability to be easily transformed with DNA containing the gonococcal uptake sequence (Goodman \& Scocca, 1988; O'Rourke \& Stevens, 1993). The size of the CPS genes themselves is conserved, except for isolates known to be deficient in CPS, for which the evidence suggests that multiple mutations led to the formation of these CPS deficiencies. Differentiation of these mutations could enable certain auxotypes of gonococci to be subtyped. The variable sequence found between $\operatorname{car} A$ and $\operatorname{car} B$ may also be useful for typing of gonococcal isolates, although more isolates currently need to be investigated to determine if the degree of variability is suitable. Large, variably sized intervening sequences were also identified in isolates of $N$. meningitidis and commensal Neisseria species, suggesting the organization of the CPS genes in $N$. gonorrboeae is widespread throughout species of the genus Neisseria. This variable sequence may be specific for the genus Neisseria or other bacterial genera which show a similar mechanism for natural competence for transformation, and similar heterogeneity. However, the organization of CPS genes we have observed in $N$. gonorrboeae $\mathrm{CH} 811$, with the large intervening sequence and putative transcription terminators downstream of both genes, is more likely to be a reflection of a significant diversity in gene structure and regulation for CPS within the prokaryotes.

\section{ACKNOWLEDGEMENTS}

We wish to thank C. Strathdee for providing the chromosomal DNA from N. meningitidis and commensal Neisseria isolates. We also thank M. Pauzé, S. Hickey, and K.-H. Yeung for providing data on the A/S/P class of the isolates. This work was partially supported by the biotechnology initiative for federal laboratories, the Natural Sciences and Engineering Research Council, and the Canadian Bacterial Diseases Network.

\section{REFERENCES}

Amuro, N., Paluh, J. L. \& Zalkin, H. (1985). Replacement by sitedirected mutagenesis indicates a role for histidine 170 in the glutamine amide transfer function of anthranilate synthase. $J$ Biol Chem 260, 14844-14849.

Barber, M., Cheng-Chang, S., Friedman, D. \& Koomey, M. (1994). Gonococcal uptake sequences act as transcription terminators in $E$. coli. Abstract D-219, p. 135. Abstracts of the 94th Annual Meeting of the American Society for Microbiology 1994.

Bhat, K. S., Gibbs, C. P., Barrera, O., Morrison, S. G., Jahnig, F., Stern, A., Kupsch, E.-M., Meyer, T. F. \& Swanson, J. (1991). The opacity proteins of Neisseria gonorrhoeae strain MS11 are encoded by a family of 11 complete genes. Mol Microbiol 5, 1889-1901.

Birnboim, H. C. \& Doly, J. (1979). A rapid alkaline extraction procedure for screening recombinant plasmid DNA. Nucleic Acids Res 7, 1513-1523.

Catlin, B.W. \& Nash, E.H. (1978). Arginine biosynthesis in gonococci isolated from patients. In Immunobiology of Neisseria gonorrboeae, pp. 1-8. Edited by G. F. Brooks, E. C. Gotschlich, K. K. Holmes, W. D. Sawyer \& F. E. Young. Washington, DC: American Society for Microbiology.

Correia, F. F., Inouye, S. \& Inouye, M. (1988). A family of small repeated elements with some Transposon-like properties in the genome of Neisseria gonorrboeae. J Biol Chem 263, 12194-12198.

Dillon, J. R., Bezanson, G. S. \& Yeung, K. H. (1985). Basic Techniques. In Recombinant DNA Methodology, pp. 1-126. Edited by J. R. Dillon, A. Nasim \& E. R. Nestmann. New York: John Wiley \& Sons.

Elkins, C., Thomas, C. E., Seifert, H. S. \& Sparling, P. F. (1991). Species-specific uptake of DNA by gonococci is mediated by a 10-base-pair sequence. J Bacteriol 173, 3911-3913.

Ghim, S.-Y., Nielsen, P. \& Neuhard, J. (1994). Molecular characterization of pyrimidine biosynthesis genes from the thermophile Bacillus caldolyticus. Microbiology 140, 479-491.

Goodman, S.D. \& Scocca, J. J. (1988). Identification and arrangement of the DNA sequence recognized in specific transformation of Neisseria gonorrboeae. Proc Natl Acad Sci USA 85, 6982-6986. 
Haas, R. \& Meyer, T. F. (1986). The repertoire of silent pilus genes in Neisseria gonorrboeae: evidence for gene conversion. Cell 44, $107-115$.

Hendry, A. T. \& Stewart, I. O. (1979). Auxanographic grouping and typing of Neisseria gonorrboeae. Can J Microbiol 25, 512-521.

Kilstrup, M., Lu, C., Abdelal, A. \& Neuhard, J. (1988). Nucleotide sequence of the $\operatorname{car} A$ gene and regulation of the $\operatorname{car} A B$ operon in Salmonella typhimurium. Eur J Biochem 176, 421-429.

Knapp, J.S., Tam, M. R., Nowinski, R. C., Holmes, K. K. \& Sandstrom, E. G. (1984). Serological classification of Neisseria gonorrboeae with use of monoclonal antibodies to gonococcal outer membrane protein I. J Infect Dis 150, 44-48.

Kwon, D.-H., Lu, C.-D., Walthall, D. A., Brown, T. M., Houghton, J. E. \& Abdelal, A. T. (1994). Structure and regulation of the car $A B$ operon in Pseudomonas aeruginosa and Pseudomonas stutzeri: no untranslated region exists. $J$ Bacteriol 176, 2532-2542.

Li, H. (1994). Evaluation of molecular typing methods to discriminate between isolates of $\mathrm{Neisseria} \mathrm{gonorrhoeae;} \mathrm{restriction} \mathrm{endonuclease} \mathrm{analysis,}$ ribotyping and pulsed field gel electrophoresis. MSc thesis. University of Ottawa, Ottawa, Canada.

Lupski, J. R. \& Weinstock, G. M. (1992). Short, interspersed repetitive DNA sequences in prokaryotic genomes. $J$ Bacteriol 174, 4525-4529.

Martin, P. R. \& Mulks, M. H. (1992). Sequence analysis and complementation studies of the argJ gene encoding ornithine acetyltransferase from Neisseria gonorrboeae. $J$ Bacteriol 174, $2694-2701$.

Martin, P. R., Cooperider, J. W. \& Mulks, M. H. (1990). Sequence of the $\operatorname{argF}$ gene encoding ornithine transcarbamoylase from Neisseria gonorrboeae. Gene 94, 139-140.

Nyunoya, H. \& Lusty, C. J. (1983). The carB gene of Escherichia coli: a duplicated gene coding for the large subunit of carbamoylphosphate synthetase. Proc Natl Acad Sci US A 80, 4629-4633.

O'Rourke, M. \& Stevens, E. (1993). Genetic structure of Neisseria gonorrboeae populations: a non-clonal pathogen. J Gen Microbiol 139, 2603-2611.
Picard, F. J. \& Dillon, J. R. (1989). Cloning and organization of seven arginine biosynthesis genes from Neisseria gonorrboeae. $J$ Bacteriol 171, 1644-1651.

Piette, J., Nyunoya, H., Lusty, C. J., Cunin, R., Weyens, G., Crabeel, M., Charlier, D., Glansdorff, N. \& Piérard, A. (1984). DNA sequence of the car $A$ gene and the control region of car $A B$ : tandem promoters, respectively controlled by arginine and the pyrimidines, regulate the synthesis of carbamoyl-phosphate synthetase in Escbericbia coli K12. Proc Natl Acad Sci US A 81, 4134 4138.

Quinn, C. L., Stephenson, B. T. \& Switzer, R. L. (1991). Functional organization and nucleotide sequence of the Bacillus subtilis pyrimidine biosynthetic operon. J Biol Cbem 266, 9113-9127.

Sanger, F., Nicklen, S. \& Coulson, A. R. (1977). DNA sequencing with chain-terminating inhibitors. Proc Natl Acad Sci USA 74, 5463-5467.

Shinners, E. N. \& Catlin, B. W. (1982). Arginine and pyrimidine biosynthetic defects in Neisseria gonorrboeae strains isolated from patients. J Bacteriol 151, 295-302.

Simmer, J. P., Kelly, R. E., Rinker, A. G., Jr, Scully, J. L. \& Evans, D. R. (1990). Mammalian carbamoyl phosphate synthetase (CPS). cDNA sequence and evolution of the CPS domain of the syrian hamster multifunctional protein CAD. $J$ Biol Chem 265, 10395-10402.

Southern, E. M. (1975). Selection of specific sequences among DNA fragments separated by gel electrophoresis. J Mol Biol 98, 503-517.

Vedros, N. A. (1984). Neisseria Trevisan 1885, 105 AL . In Bergey's Manual of Systematic Bacteriology, vol. 1, pp. 290-296. Edited by N. R. Krieg. Baltimore: Williams \& Wilkins.

West, S. E. H. \& Clark, V. L. (1989). Genetic loci and linkage associations in Neisseria gonorrboeae and Neisseria meningitidis. Clin Microbiol Rev 2, S92-S103.

Received 15 November 1994; revised 25 January 1995; accepted 2 February 1995. 